\title{
Unruptured aneurysm producing thunderclap headache treated with endovascular coil embolization
}

\author{
Endovasküler koil embolizasyonu ile tedavi edilen rüptüre olmamış anevrizmaya bağlı \\ gökgürültüsü başağrısı
}

(1) PInar GELENER, ${ }^{1,2}$ (1) Süha Halil AKPINAR ${ }^{3}$

\begin{abstract}
Summary
The abrupt onset of acute, high-intensity headache, unlike any experienced before, can be an urgent medical condition, which requires attention. A 32-year-old female patient developed thunderclap headache attacks had applied with increasing intensity and frequency since 1 week. She had visited the emergency department several times, and cranial computed tomography findings were normal. On the last presentation, neurological examination showed complete oculomotor nerve palsy on the left. Brain magnetic resonance imaging together with intracranial brain angiography revealed left posterior communicating aneurysm compressing the ipsilateral oculomotor nerve, with no evidence of subarachnoid hemorrhage. The patient was treated with endovascular balloon-assisted coil embolization of the aneurysm under digital subtraction angiography. As a result, the headache resolved soon after the intervention. Furthermore, complete ptosis recovered by the third month.

Although thunderclap headache has rarely been attributed to an enlarging unruptured cerebral aneurysm, early recognition and treatment are rather important as it may indicate a high risk of rupture.
\end{abstract}

Keywords: Coil embolization; thunderclap headache; unruptured aneurysm.

\begin{abstract}
Özet
Hastaların yaşamlarındaki en şiddetli başağrııı olarak tarifledikleri, ani olarak gelişen başağrısı oldukça dikkat edilmesi gereken bir durumdur. 32 yaşındaki kadın hasta, son bir haftadır sıklığı ve şiddeti gittikçe artan gökgürültüsü başağrısı atakları nedeniyle başvurdu. Son bir haftada birkaç kez acil başvurduğunu ve çekilen beyin tomografisinin normal olarak raporlandığını ifade etti. Son başvurusunda nörolojik muayenesinde, sol komplet okülomotor sinir felci saptandı. Beyin manyetik rezonans görüntüleme ve anjiografisinde solda posterior komunikan arter anevrizmasının ipsilateral okülomotor sinire bası yaptığı görüldü. Subaraknoid hemoraji izlenmedi. Anevrizma tedavisine yönelik endovasküler balon aracılı koil embolizasyonu yapıldı. Girişimsel işlemden hemen sonra başağrıları düzeldi. Tedavinin üçüncü ayında ise komplet ptoz düzeldi. Gökgürültüsü başağrısı, kanamamış anevrizmalarda çok sık beklenen bir durum değildir ancak gelişmekte olan bir rüptürün habercisi olabilir, bu sebeple erken tanı ve tedavi oldukça önemlidir.
\end{abstract}

Anahtar sözcükler: Gökgürültüsü başağrısı; kanamamış anevrizma; koil embolizasyonu.

\section{Introduction}

Thunderclap headache $(\mathrm{TCH})$ is a severe and explosive headache, with peak intensity at the onset, full force in less than a minute, lasting for at least 5 minutes, and often appearing without any trigger. Its occurrence is described as sudden as a "clap of a thunder." The term "thunderclap headache" was first coined in 1986 by Day and Raskin to describe a headache which was a presenting feature of an unruptured cerebral aneurysm..$^{[1,2]}$

Today, TCH is defined as an abrupt-onset headache with many other emergency conditions, such as subarachnoid hemorrhage (SAH), cerebral venous sinus thrombosis, cervical artery dissection, acute hypertensive crisis, spontaneous intracranial hypotension,

\footnotetext{
'Department of Neurology, University of Kyrenia Faculty of Medicine, North Cyprus 2Department of Neurology, Near East University Faculty of Medicine, North Cyprus ${ }^{3}$ Department of Radiology, Near East University Faculty of Medicine, North Cyprus

Correspondence: Dr. Pınar Gelener. Girne Üniversitesi Tıp Fakültesi, Nöroloji Kliniği, Karakum, Girne, K.K.T.C.

Phone:03926751000-1371 e-mail:drpinargelener@gmail.com

(C) 2018 Turkish Society of Algology
}

Submitted (Başvuru tarihi) 10.01.2017 Accepted after revision (Düzeltme sonrası kabul tarihi) 03.06.2017 Available online date (Online yayımlanma tarihi) 28.06.2018 
ischemic stroke, retroclival hematoma, pituitary apoplexy, third ventricle colloid cyst, and intracranial infection. ${ }^{[3]}$

Primary TCH is diagnosed when no underlying cause is discovered. ${ }^{[4]}$

SAH is one of the most common causes of secondary $\mathrm{TCH}$. Aneurysmal SAH accounts for the majority of cases, although other causes should also be considered, including perimesencephalic hemorrhage, arteriovenous malformation, dural arteriovenous fistula, and reversible cerebral vasoconstriction syndrome. $^{[5]}$

$\mathrm{TCH}$ related to unruptured cerebral aneurysm is not a very common entity. Different retrospective series showed that $9 \%-25 \%$ of patients presenting with TCH were found to have cerebral aneurysms, of which most were accompanied with $\mathrm{SAH} .[1,4,6]$

Although sudden and severe headache is the most common presentation of an acutely ruptured cerebral aneurysm, it is rarely due to an unruptured cerebral aneurysm in the absence of SAH. This may indicate a high risk of future rupture or growing of the aneurysm. ${ }^{[1,4,6]}$ Furthermore, some retrospective surveys of patients with SAH suggested that minor episodes with sudden headache (warning leaks) may precede the rupture of an aneurysm, and that early recognition and treatment may lead to improved outcomes. ${ }^{[7]}$

In different studies, the mechanisms underlying $\mathrm{TCH}$ due to unruptured aneurysms were diffuse, multifocal, segmental cerebral vasospasm in the absence of hemorrhage; morphologic changes, such as stretching, expansion, and dissection; ${ }^{[8]}$ local thrombosis in the wall, ${ }_{i}^{[9]}$ and limited leakage of blood, which implied partial rupture in the subarachnoid space. ${ }^{[6,10]}$

\section{Case Report}

A previously healthy 32-year-old woman developed a sudden, severe headache since 1 week. She described it as being the worst headache of her life. The attacks reached the maximum intensity in a minute, and each attack lasted for 3-4 h. Associated symptoms included neck pain, nausea, and vomiting. The headache attacks repeated during the day.
Both sides of the head and neck experienced pain. She had no history of headache. Visual analog scale (VAS) score was 10 . She had previously presented to the emergency department three times during this period with severe headache, but was discharged after limited relief. There was no apparent response to parenteral or oral NSAIDs. Cranial tomography was also performed, and the findings were normal. She could not sleep during nights because of this headache. She realized a drop in her left eyelid in her last emergency department presentation (Fig. 1). She was alert, oriented, and appropriate. There was no nuchal rigidity. Neurological examination revealed complete oculomotor nerve palsy on the left side. Computed tomography (CT) findings were normal. Brain MRI and and intracranial cerebral MRI angiography revealed saccular aneurysm of the Posterior Communicating Artery, with two associated daughter aneurysms. Balloon-assisted endovascular coil embolization of the aneurysm was performed under DSA (Fig. 2a, b). No evidence of diffuse segmental intracerebral arterial vasoconstriction was observed

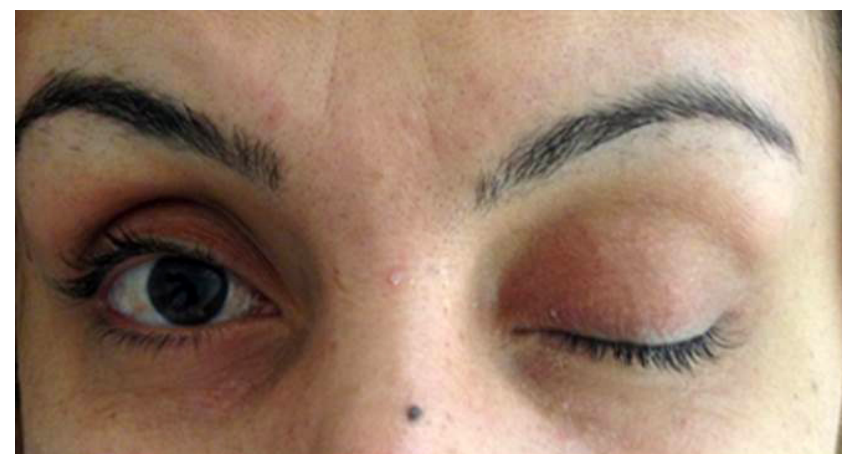

Figure 1. Complete oculomotor nerve palsy before the intervention.
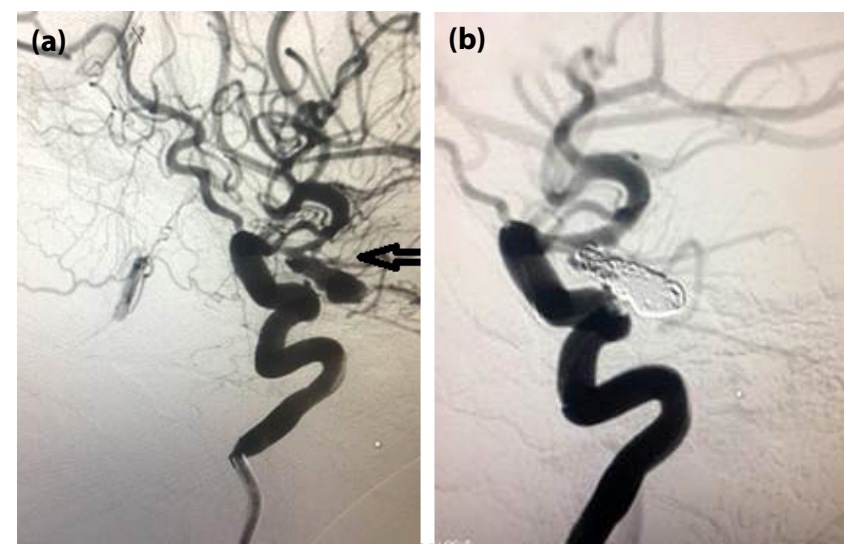

Figure 2. (a) DSA image showing the affected left ICA supraclinoid segment resulting in vascular stenosis and lobulated pcom aneurysm (arrow) projecting backward. (b) Oblique DSA image showing the near occlusive state of the aneurysm early after endovascular coil embolization. 


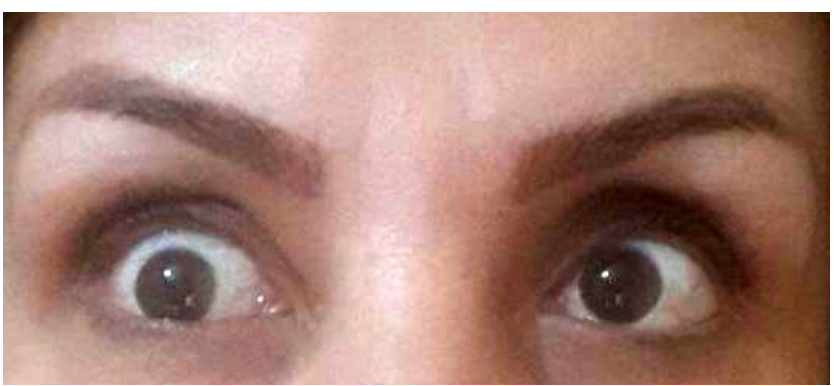

Figure 3. Resolution of the oculomotor nerve palsy 3 months after the intervention.

during DSA. After endovascular intervention, $\mathrm{TCH}$ spontaneously resolved. The patient was discharged on the third day of endovascular intervention with oral steroids and $100 \mathrm{mg}$ aspirin. Complete oculomotor nerve palsy recovered with mild ptosis in 3 months (Fig. 3). At the 1-year follow up, she had no subjective symptoms.

\section{Discussion}

TCH headache can be a signal of a very serious underlying etiology ${ }^{[2]}$ Most life-threatening secondary $\mathrm{TCH}$ conditions may present with normal brain CT findings and normal lumbar puncture, similar to that in an unruptured intracranial aneurysm. ${ }^{[1]}$

TCH triggered by any activity, including sexual activity, straining, bowel movement, or injury, and accompanied with fever; focal neurological deficits, such as weakness, loss of vision, or sensation; confusion; and changes in speech or thinking is particularly suspected to be life-threatening and need immediate evaluation. ${ }^{[2]}$

In this presented case, ictal headache associated with acute oculomotor nerve palsy necessitated further diagnostic studies, although brain CT findings were normal. In return, MR angiography showed the posterior communicating artery aneurysm associated with a high risk of rupture. We could not perform vessel wall imaging using 1.5-Tesla MRI, which could have been an early predictor. However, ruptured or unruptured intracranial aneurysm should be considered even if focal signs are absent. In this case, oculomotor nerve palsy was not present after the first TCH attack. It developed on the fifth day of the initial presentation.

In the study of Schwedt et al., ${ }^{[4]} 11 \%$ of patients with aneurysmal SAH reported a distinctive and unusual severe warning or sentinel headache in the preceding days or weeks. Furthermore, in another study by Gilard et al., ${ }^{[12]} \mathrm{TCH}$ was present in $17.5 \%$ of the study cohort with ruptured intracranial aneurysm in the previous 3 months, but not in the control cohort. This was proposed to be a sign of aneurysm instability.

In a case report, a patient who had severe headaches in the weeks before the rupture, which seemed to be caused by an unruptured cerebral aneurysm, had accompanying diffuse cerebral vasospasm. ${ }^{[10]} \mathrm{A}$ similar case was reported to have symptoms resulting from an acute aneurysmal expansion with no associated neurological deficit; the patient was treated with craniotomy and clip obliteration of the aneurysm. ${ }^{[6]}$

In a study of patients with chronic headaches before the diagnosis of an unruptured intracranial aneurysm, $89.8 \%$ reported that their headaches recovered after the treatment of the intracranial aneurysm either by surgical clipping or coil embolization. ${ }^{[13]}$ This finding is consistent with our case which showed marked relief from TCH attacks after coil embolization.

The present case describes symptomatic unruptured cerebral aneurysm producing $\mathrm{TCH}$, which resolved after endovascular coil embolization. Although TCH due to an unruptured aneurysm is an uncommon type of headache, it is a neurological emergency which mandates swift evaluation for early and accurate diagnosis, as it may be associated with significant neurological morbidity and mortality. Endovascular intervention avoided a potentially catastrophic $\mathrm{SAH}$ in this patient.

\section{Conflict-of-interest issues regarding the author- ship or article: None declared.}

\section{Peer-rewiew: Externally peer-reviewed.}

\section{References}

1. Dodick DW. Thunderclap headache. J Neurol Neurosurg Psychiatry 2002;72(1):6-11. [CrossRef]

2. Tepper D. Thunderclap Headaches. Headache 2016;56(9):1563-4. [CrossRef]

3. Ravishankar K. Looking at "thunderclap headache" differently? Circa 2016. Ann Indian Acad Neurol 2016;19(3):295301. [CrossRef] 
4. Schwedt TJ, Matharu MS, Dodick DW. Thunderclap headache. Lancet Neurol 2006;5(7):621-31. [CrossRef]

5. Mortimer AM, Bradley MD, Stoodley NG, Renowden SA. Thunderclap headache: diagnostic considerations and neuroimaging features. Clin Radiol 2013;68(3):e101-13.

6. Witham TF, Kaufmann AM. Unruptured cerebral aneurysm producing a thunderclap headache. Am J Emerg Med 2000;18(1):88-90. [CrossRef]

7. Linn FH, Wijdicks EF, van der Graaf $\mathrm{Y}$, Weerdesteyn-van Vliet FA, Bartelds Al, van Gijn J. Prospective study of sentinel headache in aneurysmal subarachnoid haemorrhage. Lancet 1994;344(8922):590-3. [CrossRef]

8. Savitz SI, Edlow J. Thunderclap headache with normal CT and lumbar puncture: further investigations are unnecessary: for. Stroke 2008;39(4):1392-3. [CrossRef]
9. Kong DS, Hong SC, Jung YJ, Kim JS. Improvement of chronic headache after treatment of unruptured intracranial aneurysms. Headache 2007;47(5):693-7. [CrossRef]

10. Day JW, Raskin NH. Thunderclap headache: symptom of unruptured cerebral aneurysm. Lancet 1986;2(8518):1247-8.

11. Moussouttas M, Mayer SA. Thunderclap headache with normal CT and lumbar puncture: further investigations are unnecessary: against. Stroke 2008;39(4):1394-5. [CrossRef]

12. Gilard V, Grangeon L, Guegan-Massardier E, SallansonnetFroment $M$, Maltête $D$, Derrey $S$, et al. Headache changes prior to aneurysmal rupture: A symptom of unruptured aneurysm? Neurochirurgie 2016;62(5):241-4. [CrossRef]

13. Kong DS, Hong SC, Jung YJ, Kim JS. Improvement of chronic headache after treatment of unruptured intracranial aneurysms. Headache 2007;47(5):693-7. [CrossRef] 